\title{
The Microstructure, Thermal Fatigue, and Failure Analysis of Near-Ternary Eutectic Sn-Ag-Cu Solder Joints
}

\author{
Sung K. Kang ${ }^{1}$, Paul Lauro ${ }^{1}$, Da-Yuan. Shih ${ }^{1}$, Donald W. Henderson ${ }^{2}$, Jay Bartelo ${ }^{2}$, \\ Timothy Gosselin ${ }^{2}$, Steve R. Cain ${ }^{2}$, Charles Goldsmith ${ }^{3}$, Karl Puttlitz ${ }^{3}$, \\ Tae K. Hwang ${ }^{4}$ and Won K. Choi ${ }^{5}$
}

${ }^{1}$ IBM, T. J. Watson Research Center, Yorktown Heights, NY 10598, USA

${ }^{2}$ IBM Microelectronics, Endicott, NY 13760, USA

${ }^{3}$ IBM Corporation, Hopewell Junction, NY 12533, USA

${ }^{4}$ Korea Adv. Inst. Sci. \& Tech., Daejeon, Korea

${ }^{5}$ Samsung Adv. Inst. Tech, Suwon, Korea

The electronic industry is making substantial progress toward a full transition to $\mathrm{Pb}$-free soldering in the near future. At present, the leading candidate $\mathrm{Pb}$-free solders are near-ternary eutectic $\mathrm{Sn}-\mathrm{Ag}-\mathrm{Cu}$ alloys. The electronic industry has begun to study both the processing behaviors and the thermo-mechanical fatigue properties of these alloys in detail in order to understand their applicability in context of current electronic card reliability requirements. In recent publications, the solidification behavior of the near-ternary eutectic $\mathrm{Sn}$ - $\mathrm{Ag}$-Cu alloys has been reported in terms of the formation of large $\mathrm{Ag}_{3} \mathrm{Sn}$ plates and their effects on mechanical properties of Pb-free solder joints. Several methods have been employed to minimize the growth of the large $\mathrm{Ag}_{3} \mathrm{Sn}$ plates in the $\mathrm{Sn}-\mathrm{Ag}-\mathrm{Cu}$ solder joints by controlling the cooling rate during solidification, reducing $\mathrm{Ag}$ and/or $\mathrm{Cu}$ content, or adding minor alloying elements which reduce the amount of undercooling required for the nucleation of tin dendrites. In the present study, the results of accelerated thermal cycle fatigue tests are reported with the near-ternary eutectic Sn-Ag-Cu alloys of reduced Ag contents. Changes in microstructure and mechanical properties are also discussed by comparing the solder joints before and after thermal cycling.

(Received September 10, 2003; Accepted December 2, 2003)

Keywords: lead-free solders, tin-silver-copper alloys, $\mathrm{A}_{3}$ Sn plates, thermal cycling test, ball grid arrays (BGA), fatigue life, failure analysis, microhardness

\section{Introduction}

\subsection{Near ternary eutectic Sn-Ag-Cu alloys}

Among several candidate Pb-free alloy systems, the nearternary-eutectic $\mathrm{Sn}-\mathrm{Ag}-\mathrm{Cu}$ alloys with a melting temperature around $217^{\circ} \mathrm{C}$ are becoming a leading candidate, ${ }^{1-3)}$ especially for SMT card assembly including BGA solder joints. The near-eutectic, commercially available alloys include Sn4.0Ag-0.5Cu, Sn-3.9Ag-0.6Cu, Sn-3.8Ag-0.7Cu, and Sn$3.0 \mathrm{Ag}-0.5 \mathrm{Cu}$ (in mass \%). In a study of solidification behavior of the near-eutectic $\mathrm{Sn}-\mathrm{Ag}-\mathrm{Cu}$ alloys, ${ }^{4)}$ it was reported that $\mathrm{Ag}_{3} \mathrm{Sn}$ plate nucleation and ensuing growth may occur with minimal undercooling. In contrast, the $\beta$-Sn phase required significantly greater undercooling in order to induce nucleation and bring about final solidification.,5) As a consequence of this disparity in the required undercooling for nucleation, large, plate-like $\mathrm{Ag}_{3} \mathrm{Sn}$ structures can grow rapidly within the liquid phase, during cooling, before the final solidification of solder joints, as reported previously. ${ }^{6-8)}$ In addition, when large $\mathrm{Ag}_{3} \mathrm{Sn}$ plates are present, adverse effects on the plastic deformation properties of the solder, ${ }^{7)}$ and plastic strain localization at the boundary between the $\mathrm{Ag}_{3} \mathrm{Sn}$ plates and bounding $\beta$-Sn phase were observed. ${ }^{6)}$ In a study involving the thermo-mechanical fatigue testing of CBGA (ceramic ball grid array) solder joints, ${ }^{8)}$ strain localization was noted to occur at the boundary between the $\mathrm{Ag}_{3} \mathrm{Sn}$ plates and the $\beta$-Sn phase, as well as preferred crack growth along the $\beta$-Sn $/ \mathrm{Ag}_{3} \mathrm{Sn}$ interface. This study also described the effective control of large $\mathrm{Ag}_{3} \mathrm{Sn}$ plate formation by increasing the cooling rate and/or reducing the $\mathrm{Ag}$ content in $\mathrm{Sn}-\mathrm{Ag}-\mathrm{Cu}$ alloys.

\subsection{Control of large $\mathrm{Ag}_{3} \mathrm{Sn}$ plate growth}

The growth of large $\mathrm{Ag}_{3} \mathrm{Sn}$ plates in $\mathrm{Sn}-\mathrm{Ag}-\mathrm{Cu}$ alloys has been extensively studied in terms of cooling rate, ${ }^{8-10)}$ alloy content, ${ }^{8,9)}$ and minor alloying elements. ${ }^{11,12)}$ The cooling rate during the reflow of $\mathrm{Sn}-\mathrm{Ag}-\mathrm{Cu}$ alloys was found to be a critical factor in controlling the formation of large $\mathrm{Ag}_{3} \mathrm{Sn}$ plates in SAC joints. ${ }^{8-10)}$ At a high-cooling rate, such as $1.5^{\circ} \mathrm{C} / \mathrm{s}$ or higher, the formation of large $\mathrm{Ag}_{3} \mathrm{Sn}$ plates can be kinetically suppressed during a reflow process. However, providing a high-cooling rate is not always practical, especially, in the case of large thermal mass chip carriers. High-cooling rate operations can also cause unwanted side effects, such as thermally induced card warpage during assembly.

To thermodynamically suppress the formation of large $\mathrm{Ag}_{3} \mathrm{Sn}$ plates in $\mathrm{Sn}-\mathrm{Ag}-\mathrm{Cu}$ alloys, the $\mathrm{Ag}$ content was reduced with a fixed $\mathrm{Cu}$ content. ${ }^{9,10)}$ It was found that large $\mathrm{Ag}_{3} \mathrm{Sn}$ plate formation was substantially reduced in alloys having a $\mathrm{Ag}$ content less than 3 mass \%, even under extremely slow cooling conditions, such as $0.02^{\circ} \mathrm{C} / \mathrm{s} .{ }^{9)}$ In addition, the $\mathrm{Cu}$ content in $\mathrm{Sn}-\mathrm{Ag}-\mathrm{Cu}$ alloys was found to have a less significant effect than $\mathrm{Ag}$ content on the formation of large $\mathrm{Ag}_{3} \mathrm{Sn}$ plates. But, lowering the $\mathrm{Cu}$ content was also found to be beneficial in reducing the so-called pasty range (the temperature range between liquidus and solidus temperature) of the molten solder, resulting in fewer joint defects. ${ }^{9)}$

Another method reported to control the growth of large $\mathrm{Ag}_{3} \mathrm{Sn}$ plates is to reduce the amount of undercooling required for the solidification of $\beta$-Sn. ${ }^{11,12}$ This can be achieved by adding minor alloying elements, such as $\mathrm{Zn}, \mathrm{Al}$, $\mathrm{Sb}$ and others to pure $\mathrm{Sn}$ or near-eutectic $\mathrm{Sn}-\mathrm{Ag}-\mathrm{Cu}$ alloys. ${ }^{13)}$ 


\subsection{Optimization of $\mathrm{Sn}$-Ag-Cu Alloy composition}

It has been demonstrated that reducing the Ag content to less than 3 mass \%, is a very effective method for minimizing the size of $\mathrm{Ag}_{3} \mathrm{Sn}$ plates in $\mathrm{Sn}-\mathrm{Ag}-\mathrm{Cu}$ alloys. The $\mathrm{Cu}$ content appears to be less sensitive than $\mathrm{Ag}$ in forming large $\mathrm{Ag}_{3} \mathrm{Sn}$ plates. ${ }^{9)}$ But a high $\mathrm{Cu}$ content can lead to the formation of large $\mathrm{Cu}_{6} \mathrm{Sn}_{5}$ rods in quantity, especially when $\mathrm{Cu}$ metallization is used in the solder joint. In addition, a high $\mathrm{Cu}$ content in $\mathrm{Sn}-\mathrm{Ag}-\mathrm{Cu}$ alloys may increase the pasty range, causing a higher defect rate. Thus, using hypoeutectic alloys in both $\mathrm{Ag}$ and $\mathrm{Cu}$ content can be beneficial in suppressing both large $\mathrm{Ag}_{3} \mathrm{Sn}$ and $\mathrm{Cu}_{6} \mathrm{Sn}_{5}$ particles and limiting its pasty range, thus reducing the reliability risk factors associated with $\mathrm{Sn}-\mathrm{Ag}-\mathrm{Cu}$ solder joints.

An additional reliability concern associated with Sn-rich solders is the allotropic transformation of white tin $(\beta-\mathrm{Sn}$, tetragonal phase) to gray tin ( $\alpha$-Sn, cubic phase) at temperatures below $13^{\circ} \mathrm{C}$ to form tin pest. ${ }^{9,14)}$ Although tin pest formation has not been reported with near-ternary $\mathrm{Sn}-\mathrm{Ag}-\mathrm{Cu}$ alloys, it would be prudent to modify the alloy composition to retard or prevent the formation of tin pest.

Based on this information, a series of modified $\mathrm{Sn}-\mathrm{Ag}-\mathrm{Cu}$ alloys was proposed for card assembly applications. ${ }^{9,15)}$ One example of a modified alloy composition is $\mathrm{Sn}-2.3 \mathrm{Ag}-0.5 \mathrm{Cu}-$ $0.2 \mathrm{Bi}$ (mass\%). A small addition of $\mathrm{Bi}$ content in the alloy can reduce the possibility of tin transformation as claimed in the literature. ${ }^{16)}$

In the present paper, thermal fatigue behavior of CBGA solder joints was investigated to assess the thermo-mechanical fatigue performance of the modified $\mathrm{Sn}-\mathrm{Ag}-\mathrm{Cu}$ compositions. The study addresses the effects of Ag-content, cooling rate, and thermal cycle conditions. Changes in the microstructure and mechanical properties of solder joints during accelerated thermal cycling (ATC) tests are discussed as well.

\section{Experimental Procedure}

\subsection{Test Vehicle description}

ATC testing was conducted utilizing $230 \mathrm{~mm} \times 280 \mathrm{~mm}(9$ in. $\times 11$ in.), mid-glass transition temperature $\left(T_{\mathrm{g}}\right)$ cards with 6 ceramic BGA modules attached as described in the previous study. ${ }^{17)}$ The $4 \mathrm{~s} 4 \mathrm{p}$ cross-section of the cards results in a $1.8 \mathrm{~mm}$ (72 mil) nominal thickness. The card BGA module sites have circular, $0.74 \mathrm{~mm}$ ( $29 \mathrm{mil}$ ) diameter, nonsoldermask defined pads. The pads are copper with an OSP surface finish. Using TMA, the effective CTE (coefficient of thermal expansion) for the card was determined to be $19 \mathrm{ppm} /{ }^{\circ} \mathrm{C}$ in the module (BGA) areas and $16 \mathrm{ppm} /{ }^{\circ} \mathrm{C}$ outside or away from those locations. These card CTEs were approximately constant throughout the ATC testing temperature range.

The $32 \mathrm{~mm} \times 32 \mathrm{~mm}$ ceramic modules containing a $25 \times$ $25 \mathrm{I} / \mathrm{O}$ grid on a $1.27 \mathrm{~mm}$ pitch were used as the ATC test vehicle. The chip carriers were $0.8 \mathrm{~mm}$ (32 mils) thick and whose CTE was approximately $6 \mathrm{ppm} /{ }^{\circ} \mathrm{C}$. No chips were attached to the carrier. Rather, a stitched pattern, provided within the carrier itself, was utilized for electrical monitoring. That is, the ceramic substrate wiring (i.e., daisy chain) and matching stitch pattern on the card, formed several concen-
Table 1 Composition, Melting Temperature, Undercooling and Microhardness of As-received Sn-Ag-Cu BGA Solder Balls.

\begin{tabular}{lccc}
$\begin{array}{c}\text { Alloy composition } \\
(\text { mass } \%)\end{array}$ & $\begin{array}{c}\text { Melting temp } \\
\left({ }^{\circ} \mathrm{C}\right)\end{array}$ & $\begin{array}{c}\text { Undercooling* } \\
\left({ }^{\circ} \mathrm{C}\right)\end{array}$ & $\begin{array}{c}\text { Microhardness } \\
(\mathrm{HVN}) * *\end{array}$ \\
\hline Sn-3.8Ag-0.7Cu & 216.9 & $25-32$ & $21.9(0.5)$ \\
Sn-2.5Ag-0.9Cu & 216.8 & $30-37$ & $19.3(0.4)$ \\
Sn-2.3Ag-0.5Cu-0.2Bi & 216.6 & $21-27$ & $20.7(0.5)$ \\
Sn-2.1Ag-0.9Cu & 216.9 & $28-33$ & $17.7(0.3)$ \\
\hline
\end{tabular}

* Undercooling $=$ onset melting temperature - onset solidification temperature.

$* * \mathrm{HVN}=$ Vickers hardness number. The standard deviation is given in parenthesis.

tric rings of BGA solder joints after attachment to the card. Each BGA solder joint that was monitored as a part of a ring was essentially the same distance from the neutral point or DNP, the point on the card where there is no differential motion with temperature changes.

\subsection{BGA Solder ball composition and card assembly}

The substrate pads on a ceramic module for ball attachment were circular in shape with a diameter of $0.86 \mathrm{~mm}$ (34 mils) and had Ni-Au metallization. Solder balls were attached to the BGA substrate by placing $0.89 \mathrm{~mm}$ (35 mils) diameter solder balls on the BGA I/O pads and reflowing them in a "balls-up" configuration at a peak temperature of about $240^{\circ} \mathrm{C}$, using a water soluble flux. The compositions of the four $\mathrm{Sn}-\mathrm{Ag}-\mathrm{Cu}$ alloys investigated are given in Table 1. The commercial alloy, $\mathrm{Sn}-3.8 \mathrm{Ag}-0.7 \mathrm{Cu}$ (SAC) served as a control alloy for comparison purposes.

The BGA modules were joined to the test card with Sn$4.0 \mathrm{Ag}-0.5 \mathrm{Cu}$ solder paste reflowed in a forced convection oven under a $\mathrm{N}_{2}$ atmosphere. Stencil printing of solder paste, component placement and other process steps followed standard SMT practices. The solder paste volume averaged about 5,500 cubic mils per pad and was reflowed using a "ramp/soak/spike" type profile. The soak or plateau was at approximately $175^{\circ} \mathrm{C}$, peak temperatures were between 235$240^{\circ} \mathrm{C}$, and time above liquidus was $70-75$ seconds. Two cooling rates were used, about $0.5^{\circ} \mathrm{C} / \mathrm{s}$ (slow) and $1.7^{\circ} \mathrm{C} / \mathrm{s}$ (fast). The BGA solder joint height, or stand-off, was measured to be about $0.60 \mathrm{~mm}(23.5$ mils $)$ after card assembly for all alloys. Moderate void formation was found in the final solder joints due to the use of solder paste during card assembly. Void formation in the $\mathrm{Pb}$-free solder joints was found to be equivalent to or slightly greater than normally found in similar $\mathrm{Sn}-\mathrm{Pb} \mathrm{SMT}$ assembled joints. The actual composition of the solder joints is expected to be slightly higher in the Ag content (by 0.15 to 0.2 mass\%) than the composition of BGA solder balls, since the solder balls were attached using the $\mathrm{Sn}-4.0 \mathrm{Ag}-0.5 \mathrm{Cu}$ solder paste.

\subsection{Accelerated thermal cycle testing}

After assembly, cards were electrically connected to the test system, mounted in fixtures, and placed in an ATC chamber. Four cards for each of the four alloys were run simultaneously in the same chamber. This procedure was undertaken to minimize any potential thermal profile differences during the comparative testing conducted on the 
four alloys for each ATC condition. Thermocouples were attached to a minimum of four cards representing edge-tocenter locations of the group within the chamber. The chambers were then run in load control and programmed until all thermocouples met the target thermal profile tolerances of $-0 /+5^{\circ} \mathrm{C}$ for the maximum profile temperature and $+0 /-5^{\circ} \mathrm{C}$ for the minimum profile temperature. The average ramp rate was in the range of 12 to $14^{\circ} \mathrm{C}$ per minute.

Three ATC test conditions were chosen with two temperature ranges $\left(0\right.$ to $100^{\circ} \mathrm{C},-40$ to $\left.+125^{\circ} \mathrm{C}\right)$ and two thermal cycle frequencies (30 and $120 \mathrm{~min}$ ) as follows;

i) ATC Test \#1: 0 to $100^{\circ} \mathrm{C}, 30$-min cycle time,

ii) ATC Test \#2: 0 to $100^{\circ} \mathrm{C}, 120$-min cycle time,

iii) ATC Test \#3: -40 to $125^{\circ} \mathrm{C}, 42$-min cycle time.

For each ATC test cell, 24 modules were monitored using 4-wire interval readouts at room temperature. All BGA joints were tested at each readout. Failures were recorded when the change in resistance of an electrical net exceeded $200 \mathrm{~m} \Omega$ from its initial resistance prior to thermal cycling. The data reported in this paper shows the cycle interval at which the first fail was identified for a particular module. In all cases, the location of the first fail was in the outermost, and highest DNP rings.

\section{Results}

\subsection{The microstructure of solder joints after assembly}

The microstructure of BGA solder joints after assembly has been examined on their cross sections for four alloy compositions and two cooling rates. Figure 1 shows a typical microstructure of a $\mathrm{Sn}-3.8 \mathrm{Ag}-0.7 \mathrm{Cu}$ joint located at a corner of a CBGA module. This solder joint was solidified at about $0.5^{\circ} \mathrm{C} / \mathrm{s}$ (slow cool) during the card attachment. The top (right) micrograph shows the microstructure near the ceramic module and the bottom (right) one is the microstructure at the card side. Due to the high Ag content and the slow cooling rate, large $\mathrm{Ag}_{3} \mathrm{Sn}$ plates grown in random directions were commonly observed. In the case of the fast-cooling rate $\left(1.75^{\circ} \mathrm{C} / \mathrm{s}\right)$ large $\mathrm{Ag}_{3} \mathrm{Sn}$ plates were less frequently observed in $\mathrm{Sn}-3.8 \mathrm{Ag}-0.7 \mathrm{Cu}$ joints. In solder joints with the reduced $\mathrm{Ag}$ content, large $\mathrm{Ag}_{3} \mathrm{Sn}$ plates were not observed in both the slow and fast-cool conditions. However, the high- $\mathrm{Cu}$ content in the initial BGA solder and $\mathrm{Cu}$ dissolution from the $\mathrm{Cu}$ pad on the test card caused large $\mathrm{Cu}_{6} \mathrm{Sn}_{5}$ rods to form near the $\mathrm{Cu}$ pad side. The presence of $\mathrm{Ni}$ is surprising in the $\mathrm{CuSn} \mathrm{IMC} \mathrm{on}$ the $\mathrm{Cu}$ pad in as-joined samples. This indicates that $\mathrm{Ni}$ diffusion occurred during joining through the molten solder from the $\mathrm{Au} / \mathrm{Ni}$ pad on a ceramic carrier to the $\mathrm{Cu}$ pad on the card. A similar result was reported previously in the study of the interfacial reactions in $\mathrm{Pb}$-free, BGA solder joints. ${ }^{18)}$ The $\beta$-Sn dendrite structure in fast-cool joints appears to be finer than in slow-cooled joints, while no apparent variation was noted among the ball locations; e.g. corner vs. middle of a ceramic carrier. However, the $\beta$-Sn dendrites were observed to be finer near the interfaces, both on the ceramic carrier and card sides, than in the middle of the solder joints. In addition, the $\beta$-Sn dendrite structure seems to be finer with a higher Ag content in $\mathrm{Sn}-\mathrm{Ag}-\mathrm{Cu}$ alloys.

It is interesting to note the presence of some curved $\mathrm{Ag}_{3} \mathrm{Sn}$ plates in the fast cooled, $\mathrm{Sn}-3.8 \mathrm{Ag}-0.7 \mathrm{Cu}$ joints, suggesting a complex growth behavior of large $\mathrm{Ag}_{3} \mathrm{Sn}$ plates.

Figure 2 exhibits another example of an as-assembled microstructure in $\mathrm{Sn}-2.5 \mathrm{Ag}-0.9 \mathrm{Cu}$ solder joints with a

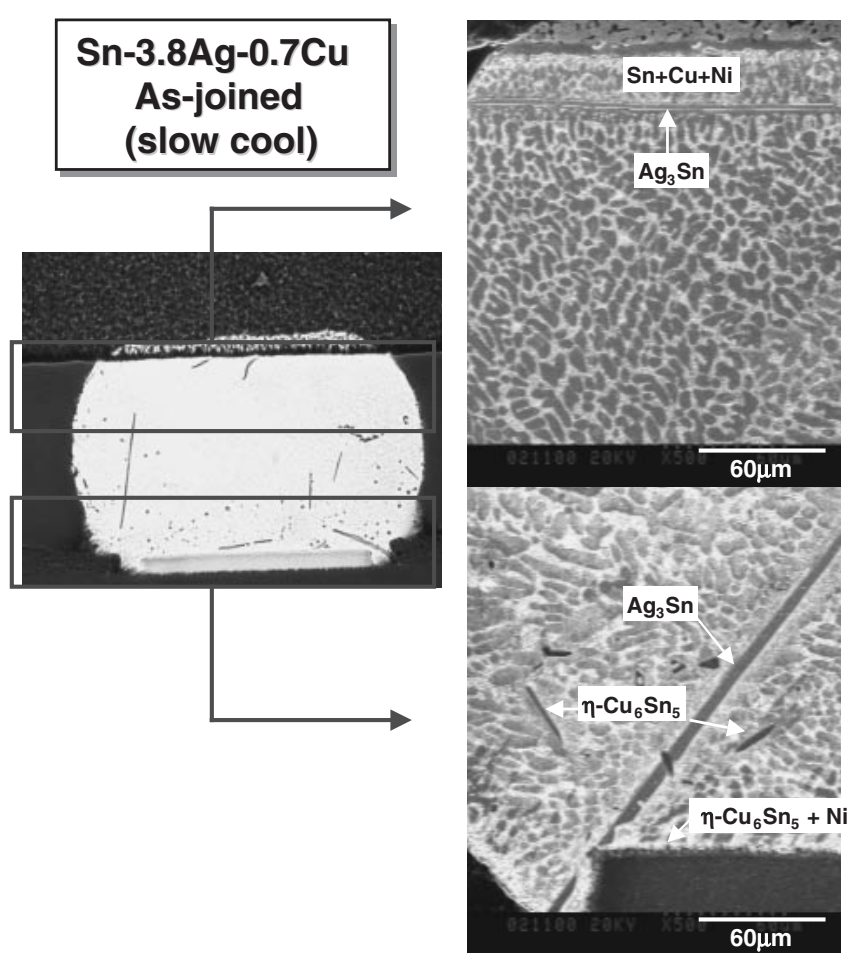

Fig. 1 SEM micrographs showing a typical microstructure of Sn-3.8Ag$0.7 \mathrm{Cu}$ joint located at a corner of a CBGA module as-assembled with the cooling rate of $0.5^{\circ} \mathrm{C} / \mathrm{s}$.

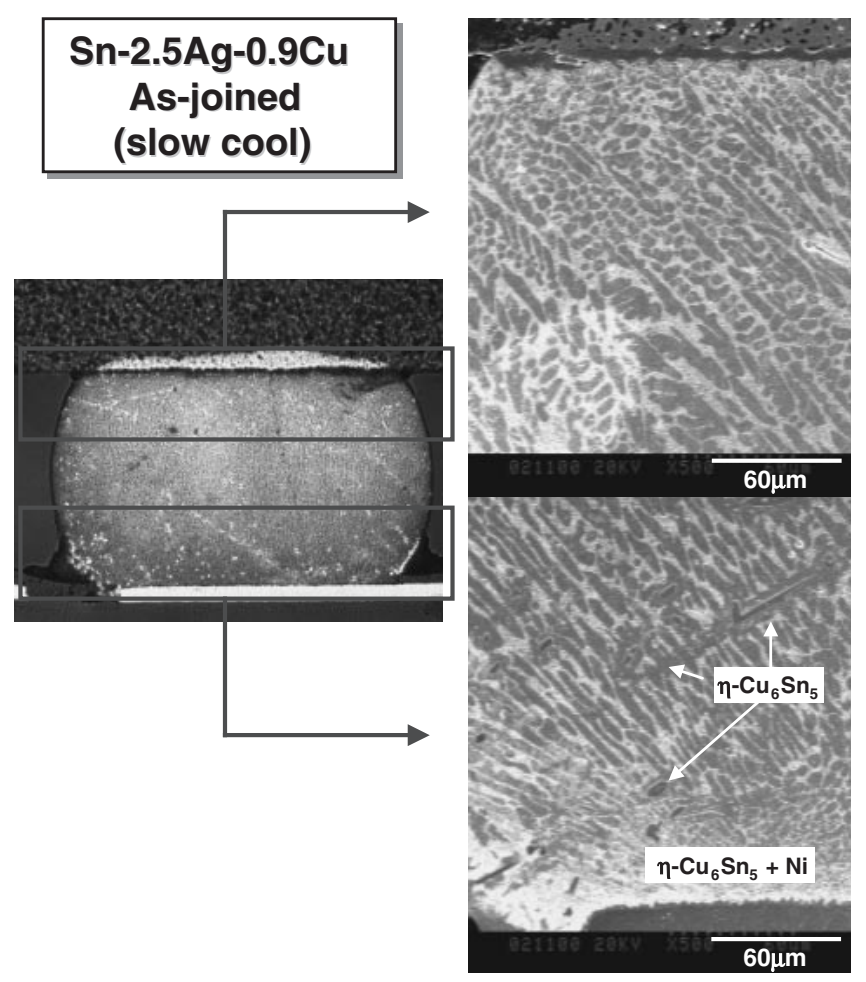

Fig. 2 SEM micrographs showing a typical microstructure of Sn-2.5Ag$0.9 \mathrm{Cu}$ joint located at a corner of a CBGA module as-assembled with the cooling rate of $0.5^{\circ} \mathrm{C} / \mathrm{s}$. 
Failure Data for $0 \mathrm{C}$ to $100 \mathrm{C}$ (30 min Cycle Time)

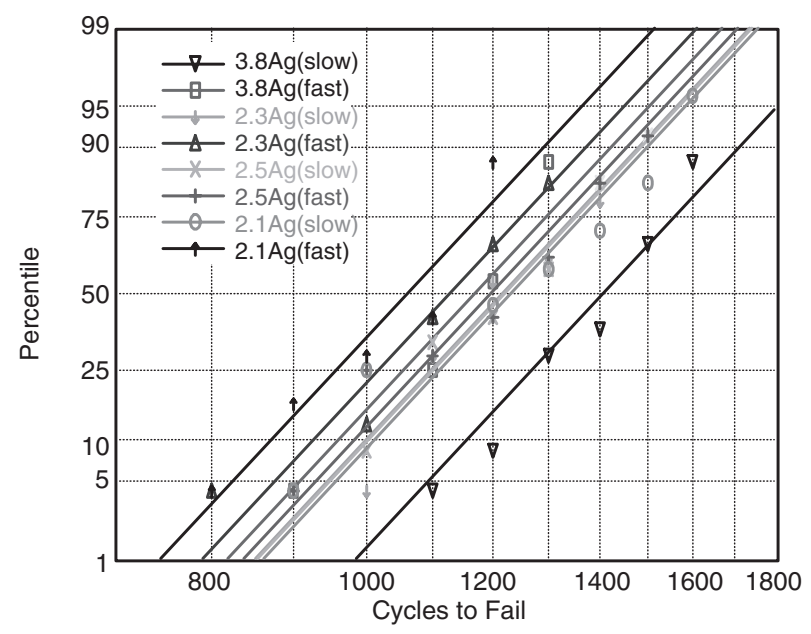

Multiple Sample Lognormal Probability Plot Global Common $\sigma=0.153$

Fig. 3 Comparison of the thermal fatigue life of $\mathrm{Sn}-\mathrm{Ag}-\mathrm{Cu}$ solder joints of CBGA carriers mounted on an organic PCB tested under the ATC condition of 0 to $100^{\circ} \mathrm{C}$ with a 30 -min cycle time.

reduced $\mathrm{Ag}$ content. Here, large, primary $\mathrm{Ag}_{3} \mathrm{Sn}$ plates were not observed anywhere even if the joints were cooled at a relative slow rate, about $0.5^{\circ} \mathrm{C} / \mathrm{s}$. Due to the high $\mathrm{Cu}$ content $(0.9 \%), \eta-\mathrm{Cu}_{6} \mathrm{Sn}_{5}$ particles were commonly noted in the asassembled microstructure. The $\beta$-Sn dendrite structure was more or less similar in size regardless of solder ball location. But within a solder ball, a finer $\beta$-Sn dendrite structure was observed near the interfaces compared with the middle of each solder joint.

\subsection{ATC failure data analysis}

The electrical failure data from three different ATC test schemes were plotted as a lognormal probability distribution for 8 different test conditions ( 4 alloys and 2 cooling rates) in Fig. 3 to Fig. 5, respectively. Because of the field service conditions, the 0 to $100^{\circ} \mathrm{C}$ ATC temperature range is probably most widely used in the computer and communication industries.

For the temperature range of 0 to $100^{\circ} \mathrm{C}$, two cycle times (30 and $120 \mathrm{~min}$ ) were used. The number of cycles to failure in each case is plotted against the probability of accumulated failure rates in percentile for 8 different test cells in Fig. 3 and Fig. 4. Failure data was analyzed assuming lognormal statistics with a global common $\sigma$ (all cells in every experiment were taken to have the same $\sigma$, which was found to be 0.1530). Parameters, obtained with the maximum likelihood method, are given in Table 2. [Note: The procedure for applying lognormal statistics is to take the natural $\log$ of the raw data, then use the more familiar normal statistics on the $\log$ of the data. Thus, $\mu=\ln \left(\mathrm{N}_{50}\right)$, where $\mathrm{N}_{50}$ is the cycle count corresponding to $50 \%$ accumulated failure.] Because all of the experimental cells had the same number of parts with nearly complete failure, the significance of the factors and interactions were evaluated with a standard factor ANOVA (analysis of variance), again using the log of the number of cycles to failure.
Failure Data for 0 C to 100 C (120min Cycle Time)

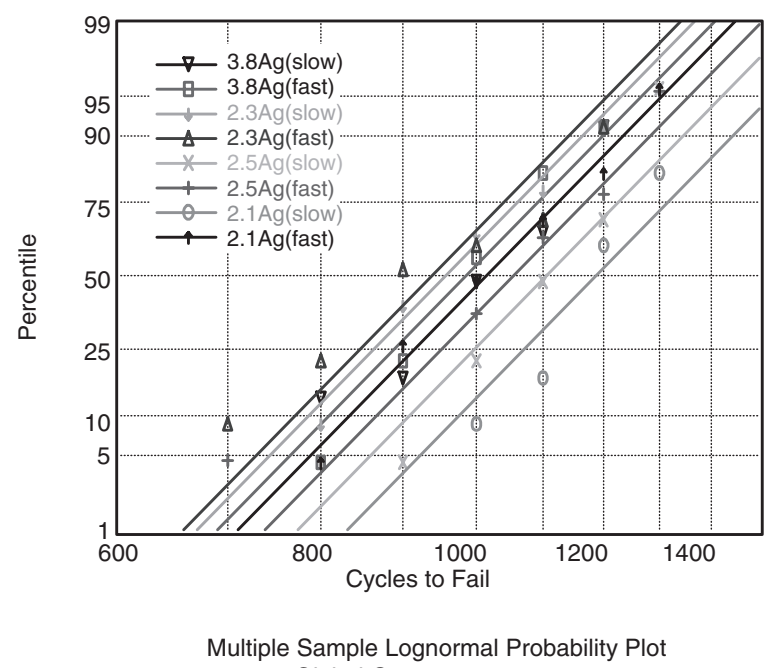

Global Common $\sigma=0.153$

Fig. 4 Comparison of the thermal fatigue life of $\mathrm{Sn}-\mathrm{Ag}-\mathrm{Cu}$ solder joints of CBGA carriers mounted on an organic PCB tested under the ATC condition of 0 to $100^{\circ} \mathrm{C}$ with a 120 -min cycle time.

\section{Failure Data for -40 C to 125 C (42min Cycle Time)}

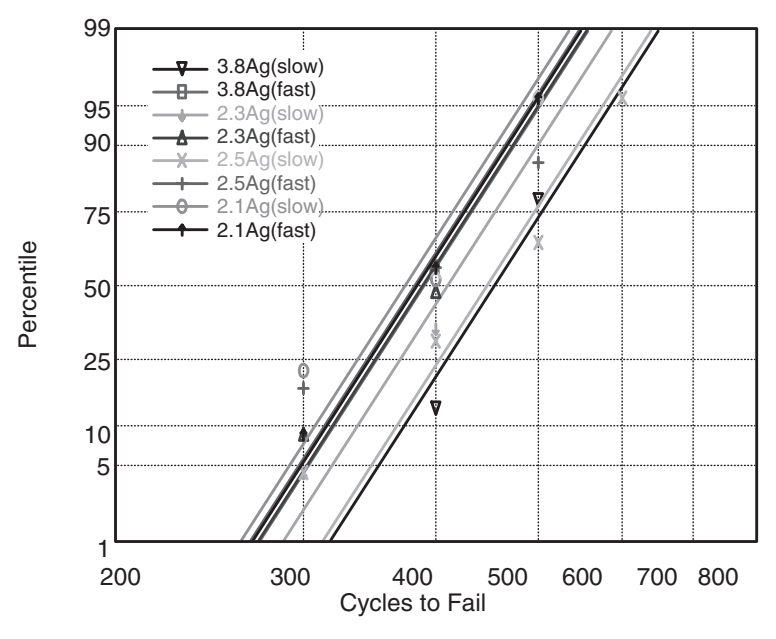

Multiple Sample Lognormal Probability Plot Global Common $\sigma=0.153$

Fig. 5 Comparison of the thermal fatigue life of $\mathrm{Sn}-\mathrm{Ag}-\mathrm{Cu}$ solder joints of CBGA carriers mounted on an organic PCB tested under the ATC condition of -40 to $125^{\circ} \mathrm{C}$ with a 42 -min cycle time.

As the cycle time is increased from $30 \mathrm{~min}$ to $120 \mathrm{~min}$ for the 0 to $100^{\circ} \mathrm{C}$ temperature range, the number of cycles to failure decreased in all cases, but more drastically for the SAC (Sn-3.8Ag-0.7Cu) and $\mathrm{Sn}-2.3 \mathrm{Ag}-0.5 \mathrm{Cu}-0.2 \mathrm{Bi}$ joints. This decrease in the number of cycle to failure is attributed to increased time for plastic strain accumulation and crack extension at the low and high temperature dwells and to the time-dependent changes that occur in the alloy microstructure, particularly at elevated temperatures. For the 30-min cycle test, the average fatigue life $\left(\mathrm{N}_{50}\right)$ is the largest for the slow-cooled SAC joints, followed by the slow-cooled joints 
Table 2 Average Fatigue Life $\left(\mathrm{N}_{50}\right)$ Estimated from ATC Failure Data of Sn-Ag-Cu BGA Solder Joints.

\begin{tabular}{|c|c|c|c|}
\hline \multirow{2}{*}{$\begin{array}{l}\text { Alloy composition } \\
\text { (cooling rate) }\end{array}$} & \multicolumn{3}{|c|}{ ATC stress conditions } \\
\hline & $\begin{array}{c}0 \text { to } 100^{\circ} \mathrm{C} \\
(30 \mathrm{~min})\end{array}$ & $\begin{array}{l}0 \text { to } 100^{\circ} \mathrm{C} \\
(120 \mathrm{~min})\end{array}$ & $\begin{array}{c}-40-125^{\circ} \mathrm{C} \\
(42 \mathrm{~min})\end{array}$ \\
\hline Sn-3.8Ag-0.7Cu (Slow) & $1,408(7.25)^{*}$ & $1,012(6.92)^{*}$ & $455(6.12)^{*}$ \\
\hline Sn-3.8Ag-0.7Cu (Fast) & $1,164(7.06)$ & $982(6.89)$ & $392(5.97)$ \\
\hline Sn-2.5Ag-0.9Cu (Slow) & $1,212(7.10)$ & $1,108(7.01)$ & $446(6.10)$ \\
\hline Sn-2.5Ag-0.9Cu (Fast) & $1,200(7.09)$ & $1,054(6.96)$ & $384(5.95)$ \\
\hline Sn-2.3Ag-0.5Cu-0.2Bi (Slow) & $1,212(7.10)$ & $953(6.86)$ & $407(6.01)$ \\
\hline Sn-2.3Ag-0.5Cu-0.2Bi (Fast) & $1,130(7.03)$ & $934(6.84)$ & $376(5.93)$ \\
\hline Sn-2.1Ag-0.9Cu (Slow) & $1,224(7.11)$ & $1,188(7.08)$ & $372(5.92)$ \\
\hline $\mathrm{Sn}-2.1 \mathrm{Ag}-0.9 \mathrm{Cu}$ (Fast) & $1,064(6.97)$ & $1,012(6.92)$ & $384(5.95)$ \\
\hline
\end{tabular}

* The value of natural logarithm of $\mathrm{N}_{50}$ is listed in parenthesis.

with $2.1 \% \mathrm{Ag}$ and $2.5 \% \mathrm{Ag}$, and the fast-cooled joints of $2.1 \% \mathrm{Ag}$ being the last. For the 120-min cycle test, this trend is reversed, where the slow cooled $2.1 \% \mathrm{Ag}$ joints shows the longest fatigue life, followed by the slow-cooled $2.5 \% \mathrm{Ag}$, and the fast cooled $2.3 \% \mathrm{Ag}$ (with $0.2 \% \mathrm{Bi}$ ) joints being the shortest. Here, the beneficial effect of low Ag content of Sn$\mathrm{Ag}-\mathrm{Cu}$ alloys on thermal fatigue life is clearly demonstrated for the 0 to $100^{\circ} \mathrm{C}$ temperature range with the 120 -min cycle time.

Figure 5 shows the failure data for the -40 to $125^{\circ} \mathrm{C}$ temperature range with a 42-min cycle time. Because of the increased peak temperatures and the larger temperature range, the number of cycles to failure drastically decreased (to about $1 / 3$ ) for the equivalent alloy and cooling condition compared to the 0 to $100^{\circ} \mathrm{C}$ test. In addition, the spread in fatigue life among the alloy compositions and cooling rates is much smaller compared to the 0 to $100^{\circ} \mathrm{C}$ test. The $3.8 \% \mathrm{Ag}$ and $2.5 \% \mathrm{Ag}$ solder joints performed slightly better than others.

In general, the slow-cooled joints survived longer than the fast-cooled joints for each alloy group for all three ATC test conditions.

\subsection{Failure analysis of thermal cycled solder joints}

Figure 6 shows a typical example of slow-cooled Sn3.8Ag-0.7Cu BGA solder joints thermal cycled from 0 to $100^{\circ} \mathrm{C}$ with the 120-min cycle. The four cross sections represent four different locations of solder joints; a corner solder joint (Ring-1), the second solder joint (Ring-2), the third (Ring-3) and the fourth (Ring-4) toward the center of the ceramic module. The temperature invariant solder joint at the center of a module, Ring-13, has a DNP value of zero. A dominant crack growth pattern is noted to be near the ceramic carrier side (top side of each micrograph), and no cracks are observed near the $\mathrm{Cu}$ pad on a PCB (bottom side). The crack propagation is observed up to the fourth ring of this module and the cracks are mostly confined to the pad/solder interface near the ceramic module. Large $\mathrm{Ag}_{3} \mathrm{Sn}$ plates that grew in random directions are readily visible in the thermal-cycled SAC joints, but do not appear to have played a role in crack propagation.

Figure 7 shows another example of the cross sectional micrographs from BGA joints of $\mathrm{Sn}-2.5 \mathrm{Ag}-0.9 \mathrm{Cu}$ (slow cool), thermal cycled from 0 to $100^{\circ} \mathrm{C}$ for $120 \mathrm{~min}$. Because of the reduced $\mathrm{Ag}$ content, no large $\mathrm{Ag}_{3} \mathrm{Sn}$ plates are noted in these cross sections. In the Ring- 1 joint, the cracks are observed both in the ceramic and in the $\mathrm{Cu}$-pad sides. In this $2.5 \mathrm{Ag}$ joint, both cracks propagated much further into the solder joint compared to the 3.8Ag joints shown in Fig. 6 . The failure analysis strongly supports the ATC test result that the low Ag joints (both $2.1 \mathrm{Ag}$ and $2.5 \mathrm{Ag}$ ) have a longer fatigue life than the $3.8 \mathrm{Ag}$ joints tested for 0 to $100^{\circ} \mathrm{C}$ with a 120-min cycle time.

The interaction of $\mathrm{Ag}_{3} \mathrm{Sn}$ plates with the crack propagation path is not clear from the cross sectional analysis of the present study, with regard to whether they facilitate or impede the crack propagation during thermal fatigue testing. Figure 8 depicts an example where the crack propagation appears to be blocked by the presence of a large $\mathrm{Ag}_{3}$ Sn plate in the crack path.

\subsection{Microhardness measurement of BGA solder joints}

To investigate the changes in mechanical properties of BGA solder joints, microhardness measurements were performed on the cross-sections of thermal-cycled samples. Nine evenly spaced measurements were made on a $3 \times 3$ grid for each sample with a Vickers indentor using a load of $25 \mathrm{~g}$. Figure 9 shows graphically the average microhardness of solder joints at a corner location of each module (Ring-1 position) in terms of solder composition, cooling rate and ATC scheme. The average microhardness of thermal cycled joints decreases as the ATC condition becomes more severe, such as with increasing $\Delta T$ or cycle time in comparison with the as-assembled sample of each group. Except for the solder joints containing $0.2 \% \mathrm{Bi}$, the average hardness gradually decreases as Ag content decreases. It is not obvious to note the effect of cooling rate on the microhardness of solder joints either as-assembled or thermal-cycled. The microhardness measurement was also performed on solder joints at the center location of each module, where the DNP is zero. The average hardness reduction of the center location was less pronounced than at the Ring-1 position after thermal cycling. This can be understood by recognizing the fact that a solder joint at the center location only experienced thermal exposure, while solder joints at the corner experienced both thermal exposure and cyclic strain. The latter facilitate microstructural changes as well as crack growth in solder joints located at the corner. 

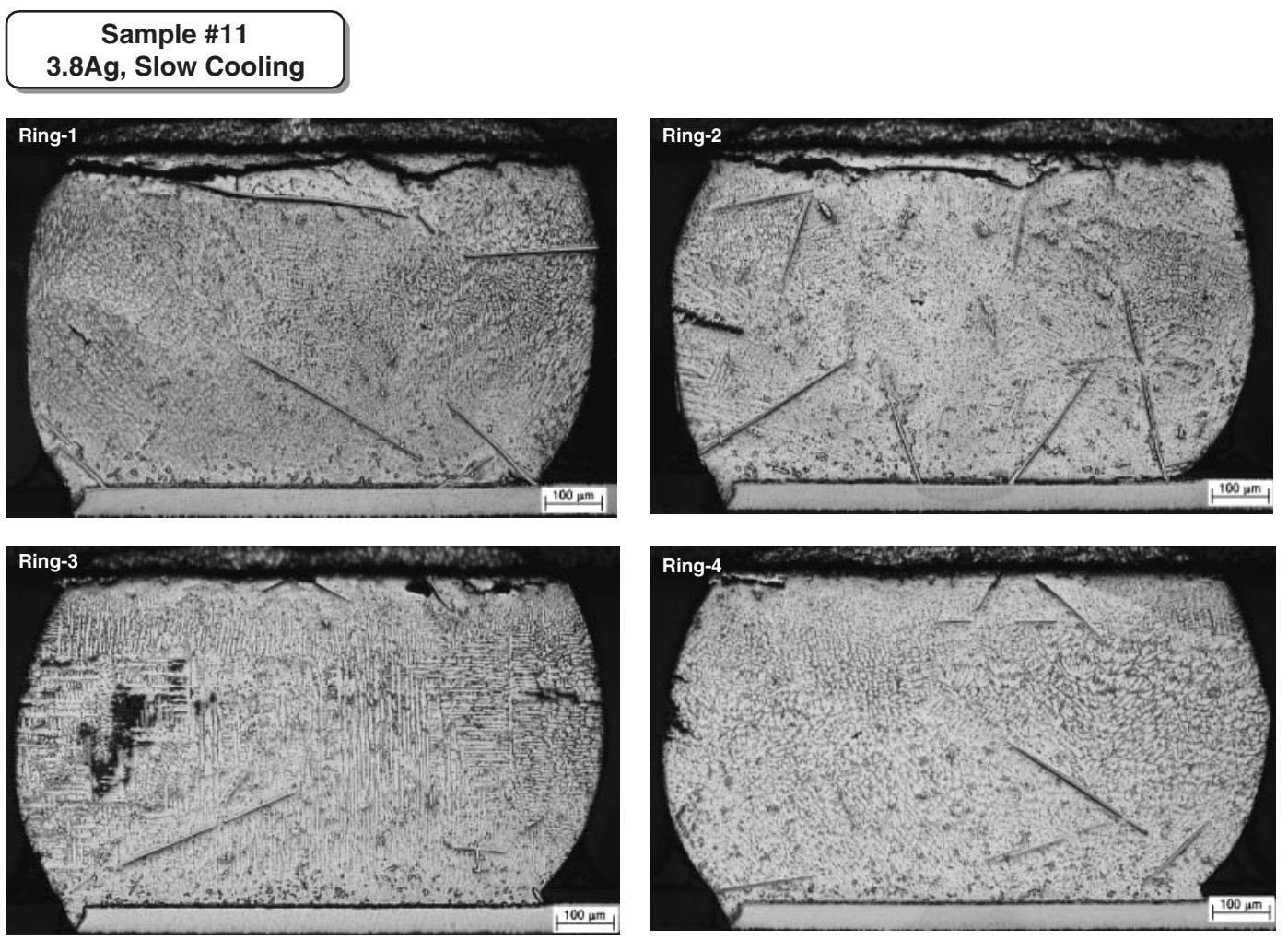

Fig. 6 Optical micrographs showing typical cross-sectional views of $\mathrm{Sn}-3.8 \mathrm{Ag}-0.7 \mathrm{Cu}$ solder joints thermal cycled from 0 to $100^{\circ} \mathrm{C}$ with a $120 \mathrm{~min}$ cycle time. Four cross sections represent four different locations of solder joints, from a corner joint (Ring-1) to fourth joint (Ring-4) inboard.
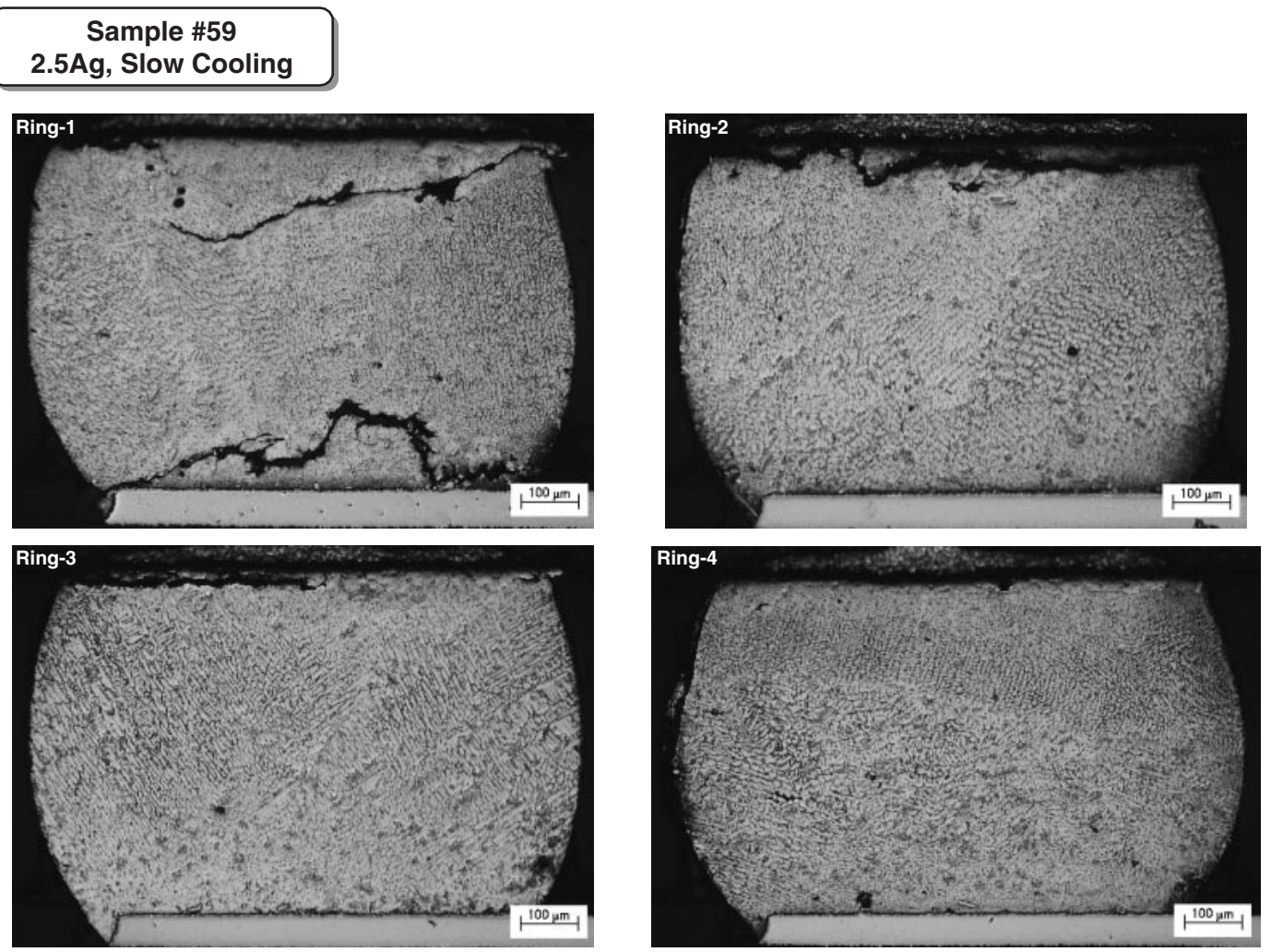

Fig. 7 Optical micrographs showing typical cross-sectional views of $\mathrm{Sn}-2.5 \mathrm{Ag}-0.9 \mathrm{Cu}$ solder joints thermal cycled from 0 to $100^{\circ} \mathrm{C}$ with a 120 min cycle time. Four cross sections represent four different locations of solder joints from a corner joint (Ring-1) to fourth joint (Ring-4) inboard. 


\section{Discussion}

\subsection{Effects of Ag content}

The microstructural characterization of both as-assembled and thermal-cycled joints identified large $\mathrm{Ag}_{3} \mathrm{Sn}$ plates in $\mathrm{Sn}-$ $3.8 \mathrm{Ag}-0.7 \mathrm{Cu}$ joints, but not in joints with a low $\mathrm{Ag}$ content, such as $2.5 \mathrm{Ag}, 2.3 \mathrm{Ag}$ or $2.1 \mathrm{Ag}$. This is consistent with the previous results that the presence of large $\mathrm{Ag}_{3} \mathrm{Sn}$ plates was critically influenced by the Ag content of the alloys. ${ }^{8-10)}$ As noted in Fig. 6, the characteristics of large $\mathrm{Ag}_{3} \mathrm{Sn}$ plates did not change much in $\mathrm{Sn}-3.8 \mathrm{Ag}-0.7 \mathrm{Cu}$ solder joints after thermal cycling tests. This also agrees with the explanation previously given that the formation of large $\mathrm{Ag}_{3} \mathrm{Sn}$ plates occurred during the solidification of solder joints. ${ }^{8-10)}$

One of the objectives of the present study was to determine if there is any beneficial effects of a low-Ag content on the thermal fatigue life of $\mathrm{Sn}-\mathrm{Ag}-\mathrm{Cu}$ solder joints. Based on the ATC data analysis, there is an advantage of a low-Ag content on thermal fatigue life in the case of a 0 to $100^{\circ} \mathrm{C}$, long-cycle time (120 min) stress condition, but not for a short-cycle time ( $30 \mathrm{~min}$ ), nor for the -40 to $125^{\circ} \mathrm{C}$ condition. For the 0 to $100^{\circ} \mathrm{C}$, 30-min cycle time test, $\mathrm{Sn}-3.8 \mathrm{Ag}-0.7 \mathrm{Cu}$ joints exhibited a longer fatigue life than low-Ag joints, although large $\mathrm{Ag}_{3} \mathrm{Sn}$ plates were observed in the $3.8 \mathrm{Ag}$ joints. This suggests the thermal fatigue behavior of $\mathrm{Sn}-\mathrm{Ag}-\mathrm{Cu}$ joints are more affected by thermal cycle conditions than the $\mathrm{Ag}$ content of the joints. Since large $\mathrm{Ag}_{3} \mathrm{Sn}$ plates are found in random directions, the presence of large $\mathrm{Ag}_{3} \mathrm{Sn}$ plates may not necessarily lead to a poor fatigue life. Considering an example shown in Fig. 8, where a large $\mathrm{Ag}_{3} \mathrm{Sn}$ plate appears to block the crack propagation, the role of large $\mathrm{Ag}_{3} \mathrm{Sn}$ plates on the fatigue life appears to be a complex issue.

One interesting result to note for low-Ag joints is that their fatigue life decreased to less extent as the cycle time increases compared to higher-Ag solder joints (e.g. Sn$3.8 \mathrm{Ag}-0.7 \mathrm{Cu}$ ). The reduced sensitivity to cycle time for lowAg joints can be explained based on microstructural differences observed among joints where Ag content differs. In particular, lowering $\mathrm{Ag}$ content in $\mathrm{Sn}-\mathrm{Ag}-\mathrm{Cu}$ alloys appears to reduce the volume fraction of the eutectic structure, and accordingly increase the volume fraction of $\beta$-Sn dendrite phase. In addition, lowering the $\mathrm{Ag}$ content appears to

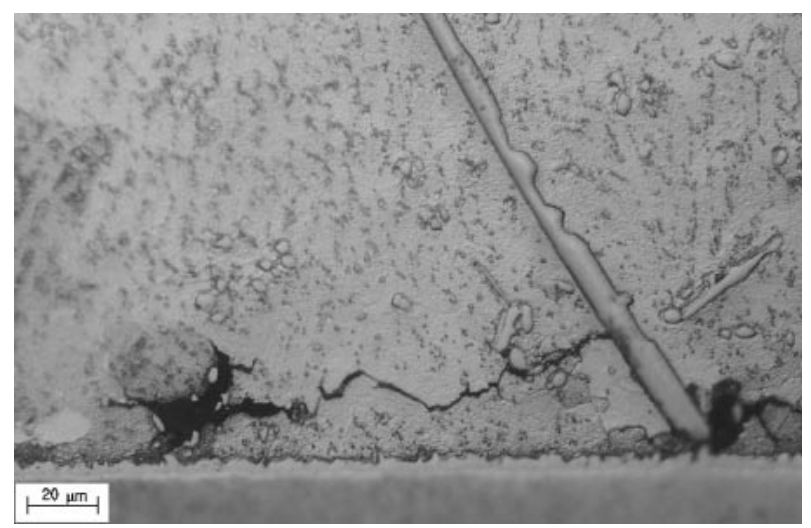

Fig. 8 Optical micrograph showing a large $\mathrm{Ag}_{3} \mathrm{Sn}$ plate blocking the propagation of a crack in $\mathrm{Sn}-3.8 \mathrm{Ag}-0.7 \mathrm{Cu}$ joint (Ring-1) near the PCB side after ATC of 0 to $100^{\circ} \mathrm{C}$ with a 120 -min cycle time. increase the $\mathrm{Sn}$ dendrite size. The microhardness measurements also support the changes in the microstructure; a decrease in microhardness as the Ag content decreases. The creep deformation of $\mathrm{Sn}-\mathrm{Ag}-\mathrm{Cu}$ alloys has been understood mainly by the deformation of the Sn dendrite phase rather than by the eutectic structure. ${ }^{19)}$ Furthermore, since creep deformation is known to be operative dominantly on grain or crystal boundaries, a coarse dendrite structure of low Ag joints is expected to be more resistant to the creep component of thermal cycling tests than high-Ag joints.

\subsection{Effects of cooling rate}

The beneficial effect of a slow-cooling rate is very clear in Table 2 for $\mathrm{Sn}-3.8 \mathrm{Ag}-0.7 \mathrm{Cu}$ joints, while the effect is less pronounced for low Ag containing joints, although the fatigue life of each alloy tested is slightly longer with slow cooling. When a solder joint is processed under a slowcooling rate, it retains less residual stress and strain after solidification, so is a positive factor in enhancing fatigue life. Since $\mathrm{Sn}-3.8 \mathrm{Ag}-0.7 \mathrm{Cu}$ is the hardest and least ductile among the solders tested, it would benefit most from slow cooling. Interestingly, the beneficial effects of slow cooling seem to override potential deleterious effects of large $\mathrm{Ag}_{3} \mathrm{Sn}$ plates found in slow-cooled joints of Sn-3.8Ag-0.7Cu.

Another factor to be considered in explaining the coolingrate effect is the microstructural difference due to cooling rate. From this study and previous ones, ${ }^{9,10)}$ slowly cooled joints (or alloys) exhibit a coarsened $\beta$-Sn dendrite structure with a lower microhardness value in comparison to fastcooled ones. When thermal fatigue would cause more timedependent deformation such as creep than pure mechanical deformation, the coarsened microstructure observed in slowcooled joints would exhibit a longer fatigue life.

The fact that the fatigue life of low Ag joints is more or less independent of cooling rate can be interpreted as an advantage of low Ag alloys, because they are less sensitive to reflow process conditions, including cooling rate, while $\mathrm{Sn}-3.8 \mathrm{Ag}-0.7 \mathrm{Cu}$ solder joints are significantly affected.

\subsection{Thermal cycle effects}

From the previous study of the thermal fatigue life of $\mathrm{Pb}$ free solder joints in comparison to $63 \mathrm{Sn}-37 \mathrm{~Pb},{ }^{17)}$ it was reported that the thermomechanical fatigue behavior of Sn$3.8 \mathrm{Ag}-0.7 \mathrm{Cu}$ was much more sensitive to the choice of ATC temperature range and peak test temperature than eutectic Sn$\mathrm{Pb}$ solder. It was also determined that the peak temperature, such as $125^{\circ} \mathrm{C}$, was a critical factor in reducing the fatigue life of $\mathrm{Sn}-3.8 \mathrm{Ag}-0.7 \mathrm{Cu}$ for a given temperature range $(\Delta T) .{ }^{17)}$ In this study, it was determined (Table 2) that for the same $\Delta T=100^{\circ} \mathrm{C}$, the longer cycle time of $120 \mathrm{~min}$ reduced the fatigue life by 10 to $30 \%$, and low-Ag joints were less affected compared to $\mathrm{Sn}-3.8 \mathrm{Ag}-0.7 \mathrm{Cu}$. For the -40 to $125 \mathrm{C}$ test $\left(\Delta T=165^{\circ} \mathrm{C}\right)$ with a 42 -min cycle time, the fatigue life was drastically reduced to about $30 \%$ of the $\Delta T=100^{\circ} \mathrm{C}$ condition. This reduction is attributed to the higher peak temperature $\left(125^{\circ} \mathrm{C}\right.$ vs. $\left.100^{\circ} \mathrm{C}\right)$ and larger $\Delta T$. Even for the more extreme test condition of -40 to $125^{\circ} \mathrm{C}$, low-Ag joints survived better than $\mathrm{Sn}-3.8 \mathrm{Ag}-0.7 \mathrm{Cu}$, although the differentiation is not remarkable.

The better thermomechanical behavior of low Ag joints 


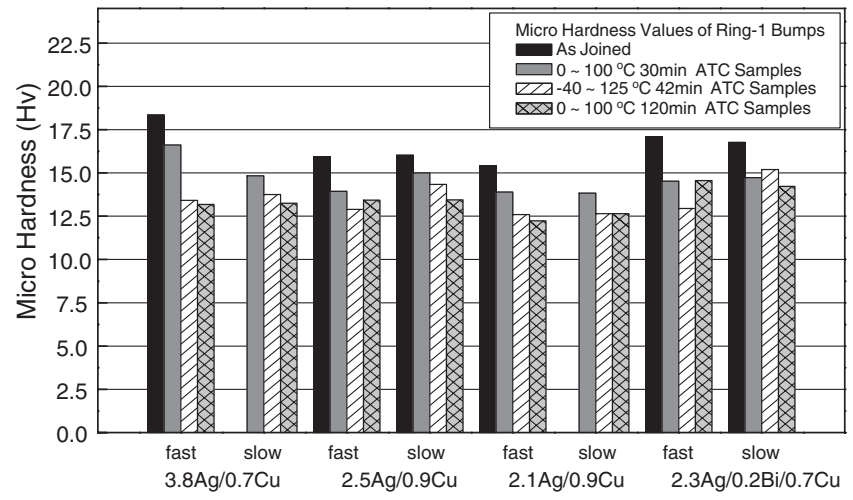

Fig. 9 Average microhardness of $\mathrm{Sn}-\mathrm{Ag}-\mathrm{Cu}$ solder joints (Ring-1 location) of Sn-Ag-Cu alloys as a function of Ag content, cooling rate, and ATC test condition. Some values of as-assembled joints are also included.

over high Ag joints, especially under the ATC condition of 0 to $100^{\circ} \mathrm{C}$ with 120 -min cycle time, may be understood in terms of their ductility or hardness properties. Based on the microhardness measurements of as-assembled joints (Fig. 9) and as-received BGA balls (Table 1), the hardness is generally lower when the Ag content is lower. This may imply that low-Ag joints have a higher ductility than high-Ag joints. The higher ductility would promote a better distribution of accumulated plastic strain over a larger joint volume, and therefore exhibit a longer fatigue life. The crack extension per cycle is also reduced by the higher solder ductility. The crack propagation patterns observed with ATC-failed joints also support this argument as shown in Fig. 6 vs. Fig. 7. For Sn-3.8Ag-0.7Cu joints, the crack generally propagated along the interface between the module and solder, while for $\mathrm{Sn}-2.5 \mathrm{Ag}-0.9 \mathrm{Cu}$ joints cracks at each interface propagated further into the solder joint, suggesting more ductility and uniform distribution of plastic strain during the ATC test.

\section{Conclusions}

The thermo-mechanical fatigue behaviors of $\mathrm{Sn}-\mathrm{Ag}-\mathrm{Cu}$ solder joints have been investigated in terms of $\mathrm{Ag}$ content, cooling rate, and ATC test condition. From this study, the following conclusions are drawn:

(1) Sn-2.1Ag-0.9Cu solder joints assembled at a slow cooling rate have the best thermal fatigue life over the high-Ag joints for the ATC test of 0 to $100^{\circ} \mathrm{C}$ with a 120 -min cycle time. (2) Sn-3.8Ag-0.7Cu solder joints assembled at a slow cooling rate have the best thermal fatigue life over other solder joints for the ATC test of 0 to $100^{\circ} \mathrm{C}$ with a 30 -min cycle time.

(3) The slow cooling rate $\left(0.5^{\circ} \mathrm{C} / \mathrm{s}\right)$ is found to be beneficial for the thermal fatigue life of $\mathrm{Sn}-\mathrm{Ag}-\mathrm{Cu}$ joints regardless of $\mathrm{Ag}$ content or ATC test scheme in comparison to the fast cooling rate $\left(1.7^{\circ} \mathrm{C} / \mathrm{s}\right)$.

(4) The thermal fatigue life of low-Ag solder joints is less dependent of the cooling rate during the assembly process in comparison to the high-Ag solder joints.

(5) The crack propagation pattern in $\mathrm{Sn}-3.8 \mathrm{Ag}-0.7 \mathrm{Cu}$ joints is more or less confined to the interface, while in low-Ag joints the crack propagation is within the solder joint. This suggests a longer fatigue life of low-Ag joints, possibly due to their greater ductility and lower hardness.

(6) The role of large $\mathrm{Ag}_{3} \mathrm{Sn}$ plates in determining the fatigue life of $\mathrm{Sn}-\mathrm{Ag}-\mathrm{Cu}$ solder joints is not clear; being detrimental only when the plates are aligned in the direction of crack propagation. Notwithstanding the fact that the presence of a large $\mathrm{Ag}_{3} \mathrm{Sn}$ plate can actually enhance fatigue life by blocking or arresting an advancing crack, it is also true they can significantly increase the reliability risk factor, thus every effort should be made to eliminate their presence.

\section{REFERENCES}

1) Japan Electronics and Information Technology Industries Association (JEITA), 2002 Lead-Free Roadmap.

2) J. Bath, C. Handwerker and E. Bradley: Circuits Assembly 11 (2000) 45-52.

3) I. E. Anderson, J. C. Foley, B. A. Cook, J. Harringa, R. K. Terpstra and O. Unal: J. Elec. Mater. 30 (2001) 1050-1059.

4) K. W. Moon, W. J. Boettinger, U. R. Kitten, F. S. Biancaniello and C. A. Handwerker: J. Electronic Mater. 29 (2000) 1122-1136.

5) I. Ohnuma, M. Miyashita, K. Anzai, X. J. Liu, H. Ohtani, R. Kainuma and K. Ishida: J. Electronic Mater. 29 (2000) 1137-1144.

6) D. R. Frear, J. W. Jang, J. K. Lin and C. Zhang: JOM 53 (2001) 28-32.

7) K. S. Kim, S. H. Huh and K. Suganuma: Mater. Sci. Eng. A333 (2002) 106-114.

8) D. W. Henderson, T. Gosselin, A. Sarkhel, S. K. Kang, W. K. Choi, D. Y. Shih, C. Goldsmith and K. Puttlitz: J. Mater. Res. 17 (2002) 2775-8.

9) S. K. Kang, W. K. Choi, D. Y. Shih, D. W. Henderson, T. Gosselin, A. Sarkhel, C. Goldsmith and K. Puttlitz: Proc. 53rd ECTC, (New Orleans, LA), May 2003, p. 64-70.

10) S. K. Kang, W. K. Choi, D. Y. Shih, D. W. Henderson, T. Gosselin, A. Sarkhel, C. Goldsmith and K. Puttlitz: JOM 55 (2003) pp. 61-65.

11) K. L. Buckmaster, J. J. Dziedzic, M. A. Masters, B. D. Poquette, G. W. Tormoen, D. Swenson, D. W. Henderson, T. Gosselin, S. K. Kang, D. Y. Shih and K. J. Puttlitz: presented at the TMS 2003 Fall Meeting, Chicago, Nov. 2003.

12) S. K. Kang, D. Y. Shih, D. Leonard, D. W. Henderson, T. Gosselin, S. I. Cho and W. K. Choi: to be presented at TMS 2004 Annual Meeting, Charlotte, NC, March, 2004.

13) A. Ohno and T. Motegi: J. Japan Inst. Metals. 37 (1973) 777-780.

14) Y. Kariya, N. William, C. Gagg and W. Plumbridge: JOM 53 (2001) 39-41.

15) D. W. Henderson, T. Gosselin, S. K. Kang, W. K. Choi, D. Y. Shih, C. Goldsmith and K. Puttlitz: US Patent filed, Feb. 15, 2002.

16) W. G. Burgers and I. J. Groen: Faraday Society, Discussion 23 (1957) p. 183.

17) J. Bartelo, S. Cain, D. Caletka, K. Darbha, T. Gosselin, D. Henderson, D. King, K. Knadle, A. Sarkhel, G. Thiel, C. Woychik, D. Y. Shih, S. K. Kang, K. Puttlitz and J. Woods: Proc. APEX 2001, January 14-18, (San Diego, CA), (2001) LF2-2.

18) S. K. Kang, W. K. Choi, D. Y. Shih, P. Lauro, D. Henderson, T. Gosselin and D. Leonard: Proc. 52nd ECTC, (San Diego, CA), May 2002, pp. 147-153.

19) J. W. Morris, H. G. Song and Fay Hua: Proc. 53rd ECTC, (New Orleans, LA), May 2003, pp. 54-57. 